\title{
Evaluation of the Viability and Seed Quality Response of Six Wheat Cultivars to Storage Conditions Form in Different Locations
}

\author{
Soad Abdelhady Elsayed, Amany Mahmoud Mohamad Mohamad and Hayam \\ Ibrahim Attia Elsawy* \\ Department of Seed Technology Research, Field Crops Research Institute, Agricultural \\ Research Center (ARC), Giza, Egypt
}

\begin{abstract}
TN THIS STUDY we evaluated different terms of wheat seeds storage form on grain quality. This study was conducted at the Seed Technology Department during 2016-2017 years to investigate the effect of some storage conditions, i.e. storage times (after harvest, 6 and 18 months), location (Sakha and Sids), form of wheat (grain and spike) and six wheat cultivars (Sakha 93, Giza 168, Sids 12, Misr 1, Gemiza 9 and Gemiza 11) of grain on the germination, seedling vigor, viability and some grain quality parameters from the wheat stored. The results revealed that, in both locations there was a significant increase in moisture content, E.C and acidity percentage due to long storage time also wheat stored in spike form is more resistant than wheat stored in grain form against adverse storage conditions by lower content of moisture, E.C and acidity percentage. The results illustrated that increasing storage period after harvest until 18 months caused negative effect on all characters. The highest values of germination percentage, seedling vigor, 1000-grain weight, relative density, protein percentage and viability parameters were recorded with wheat stored in spike form in both locations. There were highly significant differences among seed quality characters due to storage locations. Due to lower relative humidity value in Sids $(\mathrm{RH}=40 \%)$ compared to Sakha locations ( $\mathrm{RH}=80 \%$ ), Sids gave higher values for germination percentage, seedling vigor, grain viability, 1000-grain weight, relative density and protein percentage. On the other hand, results recorded highly significant differences among the tested cultivars for all studied characters mainly due to differences in the genetic constitution of these cultivars. Misr 1 then Giza 168 gave the highest values of germination percentage and seedling vigor, while Sakha 93 gave the lowest value of germination percentage and seedling vigor.
\end{abstract}

Keywords: Grain quality, Storage location, Storage time, Viability, Wheat.

\section{Introduction}

Wheat is the most important crop in Egypt. cautious storage for wheat or any crop may be very important to lessening many problems of seed viability and we can use large seed crops several times for many years of reactivation for the germ, preventing the need to depend solely on the recent crop (Nasreen, 1999). Environmental temperature and relative humidity are the most important factors influencing seed viability and longevity during storage (Abba and Lovato, 1999). Most species of seed crops could be stored safely avoiding the bad conditions by control of temperature and relative humidity in different locations all over the world, especially tropical parts, conditioned storage is very urgent to maintain the viability of some seeds still high and not highly affected from harvest time during its season to sowing time in another season (Harrington, 1973 and Nagel \& Borner, 2010). Harrington (1972) investigated that there was a relation between temperature of storage, moisture inside seeds and their longevity and then he proposed two rules of thumb according to the optimum storage (1 each $1 \%$ reduction in seed moisture increases the seeds life twice, and $\left(2\right.$ each $5^{\circ} \mathrm{C}$ reduction in seed temperature increases the seeds life twice). Also, Harrington (1972) found that there are some requirements should be available to those rules of thumb, the moisture inside seeds must not be applied above 
14 or below $5 \%$ seed moisture. The novelty here in our study is that all previous studies used grain form of wheat seed for storage forms and the spike form of wheat is not common for storage forms so, in the current study we used spike form in wheat storage. Wheat is an annual crop that consists of roots, stems, leaves and the head which is called spike. Spike is the most important part of wheat plant because the grain is formed inside it and this spike made up of zigzag central axis along that are rotation spikelets (Konopatskaia et al., 2016). Those spikelets are developed in the spikes at nodes and they contribute in the flowers and seeds improving. The grain of wheat crop surrounds the lemma and also the palea of each spikelet (Magness et al., 1971 and Miller, 2003). According to that, the spike of wheat could be considered as natural package for the grains of wheat. There is no enough information about storage of wheat in spike form, while there are many available evidences about the storage of wheat in grain form (Kibar, 2015). Wheat stored in spike form is more adaptable than wheat stored in grain form against contrary storage conditions like temperature, high moisture content, and longer time of storage (Karaoglu et al., 2010). Wheat wet gluten content and hectoliter weight are affected positively by the storage in spike form of wheat when stored in none-optimal conditions such as, high grain moisture content and high temperature. Also it can be understood that the spike form of wheat storage is almost better than grain form for its protective effect on hectoliter weight in any storage time and temperature (Karaoglu et al., 2010). This work was conducted to examine the changes in wheat grain quality that may occur during storage in different types of storage form used in different location under Egyptian conditions.

\section{Materials and Methods}

This experiment was set up at the seed Technology Research Department at two locations, Sakha Agriculture Research Station and Sids Agriculture Research Station, ARC, Egypt during 2016-2017 to investigate the effect of some storage conditions i.e.:

1- Three storage times: After harvest, 6 and 18 months

2- Two storage locations: Sakha warehouse and Sids warehouse

3- Two storage forms of wheat: grain form and spike form

Wheat cultivars

Six wheat cultivars (Sakha 93, Giza 168, Sids 12, Misr 1, Gemiza 9 and Gemiza 11) of grain were used.

\section{Studied characters}

Germination - seedling vigor - viability and some grain quality parameters from the wheat stored were studied.

The average of recorded temperatures and relative humidity of Sakha and Sids were presented in Tables 1 and 2.

TABLE 1 . The average temperature and relative humidity of Sakha during storage of the seeds

\begin{tabular}{|c|c|c|c|c|c|c|}
\hline \multirow{3}{*}{ Month } & \multicolumn{3}{|c|}{2016} & \multicolumn{3}{|c|}{2017} \\
\hline & \multicolumn{2}{|c|}{$\mathbf{T},\left({ }^{\circ} \mathbf{C}\right)$} & \multirow{2}{*}{ RH\% } & \multicolumn{2}{|c|}{$\mathbf{T},\left({ }^{\circ} \mathbf{C}\right)$} & \multirow{2}{*}{ RH\% } \\
\hline & Max & Min & & Max & Min & \\
\hline January & - & - & - & 18.20 & 5.70 & 66.00 \\
\hline February & - & - & - & 19.60 & 9.80 & 63.50 \\
\hline March & - & - & - & 22.50 & 18.00 & 61.00 \\
\hline April & - & - & - & 26.50 & 21.60 & 59.25 \\
\hline May & 30.40 & 22.8 & 72.00 & 31.90 & 23.20 & 66.75 \\
\hline June & 32.60 & 26.30 & 61.50 & 33.40 & 26.10 & 60.50 \\
\hline Jule & 33.70 & 26.10 & 59.50 & 33.90 & 27.10 & 60.00 \\
\hline August & 33.60 & 26.00 & 67.25 & 34.20 & 25.80 & 66.50 \\
\hline September & 32.70 & 24.30 & 69.65 & 33.80 & 24.90 & 66.75 \\
\hline October & 29.80 & 21.7 & 63.50 & 31.30 & 22.30 & 62.00 \\
\hline November & 24.80 & 14.40 & 63.25 & 24.90 & 17.90 & 63.00 \\
\hline December & 20.40 & 8.30 & 70.00 & 19.70 & 10.70 & 65.75 \\
\hline
\end{tabular}


TABLE 2. The average temperature and relative humidity of Sids during storage of the seeds

\begin{tabular}{|c|c|c|c|c|c|c|}
\hline \multirow{3}{*}{ Month } & \multicolumn{3}{|c|}{2016} & \multicolumn{3}{|c|}{2017} \\
\hline & \multicolumn{2}{|c|}{$\mathrm{T},(\mathrm{C})$} & \multirow{2}{*}{ RH\% } & \multicolumn{2}{|c|}{$\mathbf{T},(\mathbf{C})$} & \multirow{2}{*}{ RH\% } \\
\hline & Max & Min & & Max & Min & \\
\hline January & - & - & - & 20.00 & 11.88 & 57.00 \\
\hline February & - & - & - & 20.95 & 6.70 & 42.00 \\
\hline March & - & - & - & 24.25 & 9.87 & 41.67 \\
\hline April & - & - & - & 29.95 & 15.45 & 28.00 \\
\hline May & 33.40 & 21.8 & 29.00 & 33.77 & 19.80 & 29.33 \\
\hline June & 36.60 & 20.30 & 32.50 & 35.43 & 20.40 & 32.67 \\
\hline Jule & 37.70 & 23.10 & 33.50 & 37.90 & 23.87 & 32.50 \\
\hline August & 35.60 & 23.00 & 37.25 & 36.23 & 22.30 & 38.50 \\
\hline September & 34.90 & 19.93 & 38.33 & 35.90 & 20.93 & 38.55 \\
\hline October & 33.43 & 18.17 & 41.33 & 30.20 & 17.20 & 46.00 \\
\hline November & 26.70 & 12.73 & 49.00 & 26.00 & 11.80 & 49.00 \\
\hline December & 21.93 & 9.00 & 58.00 & 21.30 & 8.75 & 60.00 \\
\hline
\end{tabular}

Growth parameters: Root length (cm) - Shoot length $(\mathrm{cm})$ - Seedling dry weight $(\mathrm{gm})$.

Viability and vigor tests

A- Germination percentage (G.P)

Eight replications of 50 seeds per lot were planted in plastic boxes of $40 \times 20 \times 20 \mathrm{~cm}$ dimensions and contained sterilized sand. The boxes were watered and kept at $25 \mathrm{C}^{\circ}$ in an inculcated chamber for 8 days. Normal seedlings were counted at 4,8 days (first and final accounts) according to international rules of I.S.T.A (1999). Germination percentage was calculated using the following germination percentage calculated using the following outlined by Krishnasamy and Seshu (1990).

$$
\text { G.P }=\frac{\text { Number } 6 \text { normal seedlings }}{\text { Number } 6 \text { seed tested }} \times 100
$$

\section{B-Physical properties}

- Relative density (R.D):Relative density of one seed was calculated according to Kramer and Twigg (1962) as follows:

Relative density $\left(\mathrm{g} / \mathrm{mm}^{2}\right)=$

$$
\frac{100-\text { seedweight }(g)}{100-\text { seed volume }\left(\begin{array}{ll}
m & 2
\end{array}\right)}
$$

- One thousand seed weight: This was carried out according to the ISTA (1999) Regulations. This is of course to establish an indication for the specific weight of wheat grain.

- Electrical conductivity test (EC):

Four sub-samples each of 50 seeds were taken from the pure seed portion of each seed grade. Each sub-sample was weighed to the nearest two decimal points after which it was placed in 500 $\mathrm{ml}$ conical flask containing $250 \mathrm{ml}$ distilled water. The flasks were covered and then incubated at 25 $\pm 1^{\circ} \mathrm{C}$ for 24 -hour period. Conductivity measures were recorded at the end of each test period at $20{ }^{\circ} \mathrm{C}$ using a calibrated conductivity meter. The conductivity per gram of seed weight for each sub-sample was calculated as follows:

$$
\mathrm{E} . \mathrm{C}=\frac{\text { Conductivit }(\mu S) \text { for each flask }}{\text { Weight }(g) \phi \text { seed sample }}
$$$$
=\mu S) \mathrm{cm}^{-1} \mathrm{~g}^{-1}
$$

\section{C-Chemical properties}

Crude protein: - Known weight of the fine powdered seeds (ca $0.1 \mathrm{~g}$ ) was digested using a micro kjeldahl apparatus. The crude protein was calculated by multiplying the total nitrogen by 5.85 (A.O.A.C method) (1990).

\section{Statistical analysis}

Collected data were analyzed according to the factorial completely randomized design with three replicates. Analysis of variance computed according to Snedecor and Cochran (1982) and treatment means was compared by Duncan Multiple Range Test, (Duncan, 1955). Correlation performed according to Singh and Chaudhary. All statistical analyses were performed using analysis of variance technique by "MSTAT-C" (1990) computer software package. 


\section{Results and Discussion}

The general effect of storage time on the studied viability parameters of wheat grain lots are given in Tables 3 - 5. Increasing storage time after harvest to 6 and 18 months significantly decreased the mean germination percentage from $100 \%$ to $93.22 \%$ and $70.83 \%$, respectively. These findings agree with those obtained by ElSayed et al. (2004), Naguib et al. (2011), and Badwie et al. (2017) who found that the longevity of storage time and conditions affected negatively wheat viability and decreased the germination percentage. Also, similar results of soybean, zea mays and sunflower seeds germination which decreased significantly by long time storage according to El-Sayed and Abd El-Aziz (2005), Kandil et al (2013), El-Sayed and Tolba (2005) and Merda et al (2010), respectively.

The decline in germination percentage with storage time was associated with a decrease in seedling vigor [root length, shoot length and seedling dry weight] as shown in Table 3 . Increasing storage time after harvest to 6 and 18 months significantly decreased the seedling vigor from $[14,71 \mathrm{~cm}, 15.79 \mathrm{~cm}$ and $38.45 \mathrm{mg}],[12.73$ $\mathrm{cm}, 12.42 \mathrm{~cm}$ and $33.61 \mathrm{mg}$ ] and [ $8.03 \mathrm{~cm}, 7.80$ $\mathrm{cm}$ and $24.09 \mathrm{mg}$ ], respectively.

Also, in both locations the decline in germination percentage with storage time was associated with a decrease in 1000- seed weight, R.D and seed viability (by increasing E.C and acidity percentage), moisture content and crude protein percentage. The deterioration in seedling germination due to long storage time resulted in decreasing the relative density of the seeds, 1000-seeds weight then the seed viability followed it by decreasing significantly. These findings agree with those obtained by El-Sayed et al. (2004), El - Sayed and Abd El-Aziz (2005), El - Sayed and Tolba (2005) Mersal et al. (2006) and Karaoglu et al. (2010), Singh et al. (2011) Shahein and Mohamed (2016) who found similar results in different crop seeds under different storage conditions and observed that the long storage time resulted in a decrease in all of those viability parameters associated with a decrease in germination percentage.

TABLE 3. The general effect of storage time, storage location, storage form and cultivar on germination and seedling vigor (root length, shoot length and seedling dry weight)

\begin{tabular}{|c|c|c|c|c|}
\hline \multirow{2}{*}{ Treatment } & \multirow{2}{*}{$\begin{array}{c}\text { Germination } \\
\%\end{array}$} & \multicolumn{3}{|c|}{ Seedling vigor } \\
\hline & & Root length (cm) & Shoot length (cm) & $\begin{array}{l}\text { Seedling dry weight } \\
\text { (mg) }\end{array}$ \\
\hline \multicolumn{5}{|c|}{ Storage time (months) } \\
\hline After harvest & $100.0 \mathrm{a}$ & $14.71 \mathrm{a}$ & $15.79 \mathrm{a}$ & $38.45 \mathrm{a}$ \\
\hline 6 month & $93.22 \mathrm{~b}$ & $12.73 \mathrm{~b}$ & $12.42 \mathrm{~b}$ & $33.61 \mathrm{~b}$ \\
\hline 18 month & $70.83 \mathrm{c}$ & $8.03 \mathrm{c}$ & $7.80 \mathrm{c}$ & $24.09 \mathrm{c}$ \\
\hline F. test & $* *$ & $* *$ & $* *$ & $* *$ \\
\hline \multicolumn{5}{|c|}{ Storage location } \\
\hline Sakha & $85.77 \mathrm{~b}$ & $11.07 \mathrm{~b}$ & $11.53 \mathrm{~b}$ & $30.96 \mathrm{~b}$ \\
\hline Sids & $90.25 \mathrm{a}$ & $12.58 \mathrm{a}$ & $12.48 \mathrm{a}$ & $33.13 \mathrm{a}$ \\
\hline F. test & $* *$ & $* *$ & $* *$ & $* *$ \\
\hline \multicolumn{5}{|c|}{ Storage form } \\
\hline Grain & $85.75 \mathrm{~b}$ & $11.47 \mathrm{~b}$ & $11.63 \mathrm{~b}$ & $30.88 \mathrm{~b}$ \\
\hline Spike & $90.27 \mathrm{a}$ & $12.17 \mathrm{a}$ & $12.37 \mathrm{a}$ & $33.23 \mathrm{a}$ \\
\hline F. Test & $* *$ & $* *$ & $* *$ & $* *$ \\
\hline \multicolumn{5}{|c|}{ Cultivars } \\
\hline Sakha 93 & $85.11 \mathrm{~d}$ & $10.75 \mathrm{f}$ & $11.28 \mathrm{e}$ & $28.65 \mathrm{f}$ \\
\hline Giza 168 & $89.21 \mathrm{~b}$ & $12.65 \mathrm{~b}$ & $12.51 \mathrm{~b}$ & $33.59 \mathrm{~b}$ \\
\hline Sids 12 & $87.48 \mathrm{c}$ & $11.42 \mathrm{~d}$ & $11.02 \mathrm{f}$ & $30.15 \mathrm{e}$ \\
\hline Misr 1 & $91.08 \mathrm{a}$ & $13.03 \mathrm{a}$ & $13.52 \mathrm{a}$ & $36.20 \mathrm{a}$ \\
\hline Gemmiza 9 & $87.33 \mathrm{c}$ & $11.10 \mathrm{e}$ & $11.56 \mathrm{~d}$ & $31.03 \mathrm{~d}$ \\
\hline Gemmiza 11 & $87.86 \mathrm{c}$ & $11.98 \mathrm{c}$ & $12.12 \mathrm{c}$ & $32.69 \mathrm{c}$ \\
\hline F. Test & $* *$ & $* *$ & $* *$ & $* *$ \\
\hline
\end{tabular}

**, * and NS indicated $\mathrm{P}<0.01,0.05$ and not significant, respectively. 
The general effect of storage time on the mean germination percentage, seedling vigor [root length, shoot length and seedling dry weight] and studied viability parameters of wheat grain lots as affected by different storage location [Sakha warehouse and Sids warehouse] are given in Tables 3 - 5. Here, data indicated that the highest germination percentage and the best seedling vigor [ root length, shoot length and seedling dry weight] were obtained in wheat stored at Sids warehouse $90.25 \%,[12.58 \mathrm{~cm}, 12.48 \mathrm{~cm}$, and $33.13 \mathrm{mg}$, respectively. Also, the data in these tables indicates clearly that 1000 -seeds weight, Relative Density (R.D) and E.C of wheat grain were significantly affected by storage location. Here, data indicated that the highest 1000-seed weight and best R.D were obtained in wheat grain stored at Sids warehouse.

Increasing in relative humidity led to activate the fungus growth and it is a suitable media for bacterial growth (Badawi et al., 2017) so, the increase in relative humidity in the storage conditions induced deterioration in grain quality. Measuring the relative humidity in both locations, we found that it was higher in Sakha $(80 \%)$ than in Sids (40\%). In the meantime, storage at Sids warehouse recorded the highest viability [by decline EC value, Moisture content and Acidity percentage] compared with storage at Sakha warehouse. Also, Sids warehouse gave highest crude protein 13.74 compared with storage at Sakha warehouse. The results obtained were similar to those reported by other investigators, such as El-Sayed (1997), El-Sayed et al (2004), El- Sayed and Abd El-Aziz (2005), El - Sayed and Tolba (2005), they found that the increase in RH inside the storage location or packages resulted in deterioration in seeds quality especially protein content and decrease in the seeds viability.

TABLE 4. The general effect of storage time, storage location, storage form and cultivar on 1000-seed weight, R.D and E.C.

\begin{tabular}{|c|c|c|c|}
\hline Treatment & 1000-seed weight & R.D & E.C $(\mu S)$ \\
\hline \multicolumn{4}{|c|}{ Storage time (months) } \\
\hline After harvest & $44.88 \mathrm{a}$ & $1.24 \mathrm{a}$ & $15.76 \mathrm{c}$ \\
\hline 6 month & $42.94 \mathrm{~b}$ & $1.18 \mathrm{~b}$ & $18.87 \mathrm{~b}$ \\
\hline 18 month & $37.91 \mathrm{c}$ & $1.10 \mathrm{c}$ & $31.16 \mathrm{a}$ \\
\hline F. test & $* *$ & $* *$ & $* *$ \\
\hline \multicolumn{4}{|c|}{ Storage location } \\
\hline Sakha & $41.29 \mathrm{~b}$ & $1.16 \mathrm{~b}$ & $23.10 \mathrm{a}$ \\
\hline Sids & $42.54 \mathrm{a}$ & $1.18 \mathrm{a}$ & $20.75 \mathrm{~b}$ \\
\hline F. test & $* *$ & $* *$ & $* *$ \\
\hline \multicolumn{4}{|c|}{ Storage form } \\
\hline Grain & $41.25 \mathrm{~b}$ & $1.15 \mathrm{~b}$ & $23.18 \mathrm{a}$ \\
\hline Spike & $42.57 \mathrm{a}$ & $1.19 \mathrm{a}$ & $20.68 \mathrm{~b}$ \\
\hline F. Test & $* *$ & $* *$ & $* *$ \\
\hline \multicolumn{4}{|c|}{ Cultivars } \\
\hline Sakha 93 & $41.58 \mathrm{~d}$ & $1.17 \mathrm{c}$ & $0.491 \mathrm{a}$ \\
\hline Giza 168 & $36.41 \mathrm{f}$ & $1.00 \mathrm{~d}$ & $0.345 \mathrm{~d}$ \\
\hline Sids 12 & $44.47 \mathrm{~b}$ & $1.21 \mathrm{~b}$ & $0.421 \mathrm{~b}$ \\
\hline Misr 1 & $43.02 \mathrm{c}$ & $1.23 \mathrm{ab}$ & $0.269 \mathrm{e}$ \\
\hline Gemmiza 9 & $38.33 \mathrm{e}$ & $1.15 \mathrm{c}$ & $0.384 \mathrm{c}$ \\
\hline Gemmiza 11 & $47.67 \mathrm{a}$ & $1.26 \mathrm{a}$ & $0.363 \mathrm{~cd}$ \\
\hline F. Test & $* *$ & $* *$ & $* *$ \\
\hline
\end{tabular}

**, * and NS indicated $\mathrm{P}<0.01,0.05$ and not significant, respectively. 
TABLE 5. The general effect of storage time, storage location, storage form and cultivar on moisture, acidity and

\begin{tabular}{|c|c|c|c|}
\hline Treatment & $\begin{array}{c}\text { Moisture } \\
\%\end{array}$ & $\begin{array}{c}\text { Acidity } \\
\%\end{array}$ & $\begin{array}{c}\text { Crude protein } \\
\%\end{array}$ \\
\hline \multicolumn{4}{|c|}{ Storage time (months) } \\
\hline After harvest & $11.53 \mathrm{c}$ & $0.222 \mathrm{c}$ & $14.15 \mathrm{a}$ \\
\hline 6 month & $11.58 \mathrm{~b}$ & $0.337 \mathrm{~b}$ & $14.01 \mathrm{~b}$ \\
\hline 18 month & $12.82 \mathrm{a}$ & $0.577 \mathrm{a}$ & $12.64 \mathrm{c}$ \\
\hline F. test & $* *$ & $* *$ & $* *$ \\
\hline \multicolumn{4}{|c|}{ Storage location } \\
\hline Sakha & $12.32 \mathrm{a}$ & $0.403 \mathrm{a}$ & $13.47 \mathrm{~b}$ \\
\hline Sids & $11.63 \mathrm{~b}$ & $0.355 \mathrm{~b}$ & $13.74 \mathrm{a}$ \\
\hline F. test & $* *$ & $* *$ & $* *$ \\
\hline \multicolumn{4}{|c|}{ Storage form } \\
\hline Grain & $12.21 \mathrm{a}$ & $0.401 \mathrm{a}$ & $13.51 \mathrm{~b}$ \\
\hline Spike & $11.75 \mathrm{~b}$ & $0.357 \mathrm{~b}$ & $13.69 \mathrm{a}$ \\
\hline F. Test & $* *$ & $* *$ & $* *$ \\
\hline \multicolumn{4}{|c|}{ Cultivars } \\
\hline Sakha 93 & $12.49 \mathrm{a}$ & $0.491 \mathrm{a}$ & $13.97 \mathrm{a}$ \\
\hline Giza 168 & $11.70 \mathrm{~d}$ & $0.345 \mathrm{~d}$ & $12.97 \mathrm{~b}$ \\
\hline Sids 12 & $11.95 \mathrm{c}$ & $0.421 \mathrm{~b}$ & 13.79 a \\
\hline Misr 1 & $11.42 \mathrm{e}$ & $0.269 \mathrm{e}$ & $13.29 \mathrm{~b}$ \\
\hline Gemmiza 9 & $12.19 \mathrm{~b}$ & $0.384 \mathrm{c}$ & $14.22 \mathrm{a}$ \\
\hline Gemmiza 11 & $12.09 \mathrm{bc}$ & $0.363 \mathrm{~cd}$ & $13.35 \mathrm{~b}$ \\
\hline F. Test & $* *$ & $* *$ & $* *$ \\
\hline
\end{tabular}

**, * and NS indicated $\mathrm{P}<0.01,0.05$ and not significant, respectively.

The general effect of storage form on germination percentage, seedling vigor [ root length, shoot length and seedling dry weight], 1000- seed weight, R.D, E.C, moisture content, acidity percentage and crude protein percentage are shown in Tables 3-5. Germination percentage, seedling vigor (root length, shoot length and seedling dry weight) of wheat stored in spike form $90.27 \%(12.17 \mathrm{~cm}, 12.37 \mathrm{~cm}$ and $33.23 \mathrm{mg})$ were significantly higher than those of wheat stored grain form $85.75 \%,(11.47 \mathrm{~cm}, 11.63 \mathrm{~cm}$ and $30.88 \mathrm{mg}$ ), respectively. In the meantime, wheat stored spike form recorded the highest value of 1000-seed weight and R.D (42.57 g and 1.19), respectively. The lowest viability (by increasing E.C. value) was recorded at storage in grain form. Also, Table 5 indicates that moisture content and acidity percentage of wheat stored in spike form were significantly lower than those of wheat stored in grain form $(11.75 \%, 0.357 \%)$, $(12.21 \%, 0.401 \%)$, respectively. On the other hand, crude protein percentage of wheat stored in spike form were significantly higher than those of wheat stored in grain form. Karaoglu et al. (2010) recorded that storage in spike form had generally better preserving effect on hectoliter weight than storage in grain form at all storage time and temperature.

Tables 3-5 indicate that the germination percentage and seedling vigor (root length, shoot length and seedling dry weight) of wheat seeds were significantly affected by cultivars; Misr 1 was significantly higher in germination percentage and seedling vigor (root length, shoot length and seedling dry weight), $91.08 \%(13.03 \mathrm{~cm}, 13.52$ $\mathrm{cm}$ and $36.20 \mathrm{mg}$ ), respectively. Gemmize 11 was significantly higher in 1000- seed weight and R.D. (47.67 g and 1.26), respectively. Sakha 93 was significantly lower in germination percentage $(85.11 \%)$, while higher in moisture content and acidity percentage $(12.49 \%, .491 \%)$. Meantime, Gemmiza 9 was significantly higher in crude protein percentage $(14.22 \%)$. These results agreed with those reported by Naguib et al. (2011) and 
Omar et al. (2012) because they proveded that the different cultivars of wheat behaved differentially by storage conditions and they observed the epistasis of cultivar Misr1 and its ability to resist the storage condition stresses. With respect to the first order interaction (storage time and storage location, Table 6 indicates that germination percentage declined to $65.41 \%$ and $76.25 \%$ when stored at Sakha and Sids warehouse, respectively after 18 months of storage.

It is also observed a decline in seedling vigor (root length, shoot length and seedling dry weight \}, 1000-seed weight, R.D. and crude protein percentages: $(6.43 \mathrm{~cm}, 6.89 \mathrm{~cm}$ and $20.19 \mathrm{mg}$ ), $36.94 \mathrm{~g}, 1.07$ and 12.29 percentage when stored at Sakha warehouse compared with storage at Sids warehouse $(9.63 \mathrm{~cm}, 8.71 \mathrm{~cm}$ and $28 \mathrm{mg}$ ), $38.88 \mathrm{~g}, 1.13$ and 13 percentages. Rapid decline in viability parameter (by increase E.C value, moisture content and acidity percentage) after 18 months of storage at Sakha warehouse storage compared with Sids warehouse (33.27, $13.61 \%, 0.627 \%)$ and $(27.90,12.03 \%, 0.527 \%)$, respectively. Similar results were observed by El- Borai et al. (1993) in soy bean seeds and similar results were reported by Copeland and MC Donald (1995), El- Sayed (1997), El- Sayed and Abd El-Aziz (2005) and El - Sayed \& Tolba (2005) in different crop seeds affected by storage in different locations and conditions and their seedling vigor and quality decreased significantly.

Regarding the first order interaction between storage time and storage form Table 7 , the decrease in germination percentage, seedling vigor (root length, shoot length and seedling dry weight), 1000-seed weight, R.D of wheat stored in grain form were greater than of wheat stored in spike form at the end of 18 months of storage [66.33\% (7.47cm, $7.05 \mathrm{~cm}, 21.50 \mathrm{mg}), 36.21 \mathrm{~g}$, $1.07]$ and $[75.32 \%,(8.60 \mathrm{~cm}, 8.55 \mathrm{~cm}, 26.69$ $\mathrm{mg}), 39.62 \mathrm{~g}, 1.13]$, respectively. In addition to this, the storage in grain form was affected by the increase of grain moisture content, E.C and acidity percentage more than storage in spike form at the end of 18 months of storage. Storage in spike form had generally a better preserving effect on germination percentage, seedling vigor, and protein percentage and grain viability (by decreasing EC value, moisture content and acidity percentage) than storage in grain form for all storage time. The reduction in 1000- seeds weight is mainly attributable to the decrease in grain density during storage time. Similar results were found by other researchers who investigated the effect of storage at high moisture content and temperature on functional characteristics of wheat, 1000- seed weight decreased as the duration on the storage time increased (Odiemah 1987 and Srivastava \& Rae. 1994). It may be said that, wheat stored in spike form is more tolerant than wheat stored in grain form to adverse storage condition (Karaoglu et al., 2010).

The interaction effect between storage time and storage location in both spike and grain form is shown in Table 8 . The highest germination \%, and seedling vigor (root length, shoot length and seedling dry weight) were noted with spike form at Sids warehouse at 6 and 18 months $[96.80 \%$, $(13.81 \mathrm{~cm}, 13.12 \mathrm{~cm}$ and $34.06 \mathrm{mg})],[79.59 \%$, $(10.01 \mathrm{~cm}, 9.53 \mathrm{~cm}$ and $30.83 \mathrm{mg})]$, respectively. Meanwhile, with grain form under Sakha warehouse recorded a great decline viability (by increasing EC value, moisture $\%$ and acidity \%)

TABLE 6. Interaction effect of storage Time and Storage location on germination, seedling vigor, 1000-seed weight, R.D, E.C, moisture, acidity and crude protein

\begin{tabular}{|c|c|c|c|c|c|c|c|c|c|c|c|}
\hline \multirow[b]{2}{*}{ Storage time } & \multirow[b]{2}{*}{$\begin{array}{l}\text { Storage } \\
\text { location }\end{array}$} & \multirow[b]{2}{*}{ Germination \% } & \multicolumn{3}{|c|}{ Seedling vigor } & \multirow[b]{2}{*}{$\begin{array}{c}1000- \\
\text { seed } \\
\text { weight }\end{array}$} & \multirow[b]{2}{*}{ R.D } & \multirow[b]{2}{*}{$\begin{array}{l}\text { E.C } \\
(\mu S)\end{array}$} & \multirow[b]{2}{*}{$\begin{array}{c}\text { Moisture } \\
\%\end{array}$} & \multirow[b]{2}{*}{$\begin{array}{c}\text { Acidity } \\
\%\end{array}$} & \multirow[b]{2}{*}{$\begin{array}{c}\text { Crude } \\
\text { protein } \\
\%\end{array}$} \\
\hline & & & $\begin{array}{c}\text { Root } \\
\text { length } \\
9 \mathrm{~cm})\end{array}$ & $\begin{array}{l}\text { Shoot } \\
\text { length } \\
(\mathrm{cm})\end{array}$ & $\begin{array}{c}\text { Seedling } \\
\text { dry } \\
\text { weight } \\
(\mathrm{mg}) \\
\end{array}$ & & & & & & \\
\hline \multirow[t]{2}{*}{ After harvest } & Sakha & 100 & 14.71 & 15.74 & 38.45 & 44.88 & 1.24 & 15.76 & 11.53 & 0.222 & 14.15 \\
\hline & Sids & 100 & 14.71 & 15.74 & 38.45 & 44.88 & 1.24 & 15.76 & 11.53 & 0.222 & 14.15 \\
\hline \multirow[t]{2}{*}{6 months } & Sakha & 91.92 & 12.08 & 11.94 & 32.95 & 42.04 & 1.16 & 19.33 & 11.83 & 0.360 & 13.96 \\
\hline & Sids & 94.51 & 13.39 & 12.90 & 34.28 & 43.85 & 1.19 & 18.20 & 11.22 & 0.315 & 14.06 \\
\hline \multirow[t]{2}{*}{18 months } & Sakha & 65.41 & 6.43 & 6.89 & 20.19 & 36.94 & 1.07 & 33.27 & 13.61 & 0.627 & 12.29 \\
\hline & Sids & 76.25 & 9.63 & 8.71 & 28.00 & 38.88 & 1.13 & 27.90 & 12.03 & 0.528 & 13.00 \\
\hline \multicolumn{2}{|c|}{ F. test } & $* *$ & $* *$ & $* *$ & $* *$ & $* *$ & $* *$ & $* *$ & $* *$ & $* *$ & $* *$ \\
\hline \multicolumn{2}{|c|}{ L.S.D 5\% } & 0.782 & 0.237 & 0.193 & 0.640 & 0.372 & 0.025 & 0.318 & 0.147 & 0.026 & 0.332 \\
\hline
\end{tabular}

**, * and NS indicated $\mathrm{P}<0.01,0.05$ and not significant, respectively. 
TABLE 7. Interaction effect of storage time and Storage form on germination, seedling vigor, 1000-seed weight R.D, E.C, moisture, acidity and crude protein

\begin{tabular}{|c|c|c|c|c|c|c|c|c|c|c|c|}
\hline \multirow[b]{2}{*}{$\begin{array}{l}\text { Storage } \\
\text { time }\end{array}$} & \multirow[b]{2}{*}{$\begin{array}{c}\text { Storage } \\
\text { form }\end{array}$} & \multirow[b]{2}{*}{ Germination \% } & \multicolumn{3}{|c|}{ Seedling vigor } & \multirow{2}{*}{$\begin{array}{c}1000- \\
\text { seed } \\
\text { weight }\end{array}$} & \multirow[b]{2}{*}{ R.D } & \multirow[b]{2}{*}{$\begin{array}{l}\text { E.C } \\
(\mu S)\end{array}$} & \multirow[b]{2}{*}{$\begin{array}{c}\text { Moisture } \\
\%\end{array}$} & \multirow[b]{2}{*}{$\begin{array}{c}\text { Acidity } \\
\%\end{array}$} & \multirow{2}{*}{$\begin{array}{c}\text { Crude } \\
\text { protein } \\
\%\end{array}$} \\
\hline & & & $\begin{array}{c}\text { Root } \\
\text { length } \\
9 \mathrm{~cm})\end{array}$ & $\begin{array}{l}\text { Shoot } \\
\text { length } \\
\text { (cm) }\end{array}$ & $\begin{array}{l}\text { Seedling } \\
\text { dry weight } \\
\text { (mg) }\end{array}$ & & & & & & \\
\hline \multirow[t]{2}{*}{$\begin{array}{c}\text { After } \\
\text { harvest }\end{array}$} & Grain & 100 & 14.71 & 15.74 & 38.45 & 44.88 & 1.24 & 15.76 & 11.53 & 0.222 & 14.15 \\
\hline & Spike & 100 & 14.71 & 15.74 & 38.45 & 44.88 & 1.24 & 15.76 & 11.53 & 0.222 & 14.15 \\
\hline \multirow[t]{2}{*}{6 months } & Grain & 90.94 & 12.24 & 12.10 & 32.70 & 42.67 & 1.16 & 19.33 & 11.82 & 0.370 & 13.96 \\
\hline & Spike & 95.48 & 13.22 & 12.75 & 34.53 & 43.21 & 1.19 & 18.06 & 11.23 & 0.305 & 14.06 \\
\hline \multirow[t]{2}{*}{$\begin{array}{c}18 \\
\text { months }\end{array}$} & Grain & 66.33 & 7.47 & 7.05 & 21.50 & 36.21 & 1.07 & 33.27 & 13.24 & 0.611 & 12.29 \\
\hline & Spike & 75.32 & 8.60 & 8.55 & 26.69 & 39.62 & 1.13 & 27.89 & 12.39 & 0.544 & 13.00 \\
\hline F. test & & $* *$ & $* *$ & $* *$ & $* *$ & $* *$ & $* *$ & $* *$ & $* *$ & $* *$ & $* *$ \\
\hline $\begin{array}{c}\text { L.S.D } \\
5 \%\end{array}$ & & 0.783 & 0.237 & 0.193 & 0.640 & 0.372 & 0.255 & 0.318 & 0.147 & 0.023 & 0.332 \\
\hline
\end{tabular}

TABLE 8. Interaction effect of Time storage, location storage and Storage form on germination, seedling vigor (root length and shoot length and seedling dry weight)

\begin{tabular}{|c|c|c|c|c|c|c|c|c|c|}
\hline \multirow[b]{2}{*}{ Storage time } & \multirow[b]{2}{*}{$\begin{array}{l}\text { Storage } \\
\text { location }\end{array}$} & \multirow[b]{2}{*}{$\begin{array}{l}\text { Storage } \\
\text { form }\end{array}$} & \multirow[b]{2}{*}{ Germination \% } & \multicolumn{3}{|c|}{ Seedling vigor } & \multirow[b]{2}{*}{$\begin{array}{l}\text { E.C } \\
(\mu S)\end{array}$} & \multirow[b]{2}{*}{$\begin{array}{c}\text { Moisture } \\
\%\end{array}$} & \multirow[b]{2}{*}{$\begin{array}{c}\text { Acidity } \\
\%\end{array}$} \\
\hline & & & & $\begin{array}{l}\text { Root } \\
\text { length } \\
\text { (cm) }\end{array}$ & $\begin{array}{l}\text { Shoot } \\
\text { length } \\
(\mathrm{cm})\end{array}$ & $\begin{array}{l}\text { Seedling dry } \\
\text { weight (mg) }\end{array}$ & & & \\
\hline \multirow[t]{4}{*}{$\begin{array}{c}\text { After } \\
\text { harvest }\end{array}$} & Sakha & Grain & 100 & 14.71 & 15.74 & 38.45 & 15.76 & 11.53 & 0.222 \\
\hline & & Spike & 100 & 14.71 & 15.74 & 38.45 & 15.76 & 11.53 & 0.222 \\
\hline & Sids & Grain & 100 & 14.71 & 15.74 & 38.45 & 15.76 & 11.53 & 0.222 \\
\hline & & Spike & 100 & 14.71 & 15.74 & 38.45 & 15.76 & 11.53 & 0.222 \\
\hline \multirow[t]{4}{*}{6 months } & Sakha & Grain & 89.69 & 11.52 & 11.51 & 33.56 & 20.24 & 12.13 & 0.398 \\
\hline & & Spike & 94.17 & 12.63 & 12.38 & 35.00 & 18.42 & 11.53 & 0.323 \\
\hline & Sids & Grain & 92.22 & 12.97 & 12.68 & 31.83 & 19.11 & 11.69 & 0.342 \\
\hline & & Spike & 96.80 & 13.81 & 13.12 & 34.06 & 17.07 & 11 & 0.288 \\
\hline \multirow[t]{4}{*}{18 months } & Sakha & Grain & 59.76 & 5.67 & 6.22 & 17.83 & 35.12 & 14.16 & 0.671 \\
\hline & & Spike & 71.06 & 7.19 & 7.55 & 22.56 & 31.41 & 13.06 & 0.582 \\
\hline & Sids & Grain & 72.91 & 9.26 & 7.89 & 25.17 & 30.59 & 12.32 & 0.550 \\
\hline & & Spike & 79.59 & 10.01 & 9.53 & 30.83 & 25.20 & 11.73 & 0.507 \\
\hline \multicolumn{2}{|c|}{ F. test } & $* *$ & $* *$ & $* *$ & $* *$ & $* *$ & $* *$ & $* *$ & $* *$ \\
\hline \multicolumn{2}{|c|}{ L.S.D 5\% } & & 1.107 & 0.335 & 0.273 & 0.905 & 0.450 & 0.207 & 0.036 \\
\hline
\end{tabular}


with all time storage.

The germination percentage, root length, and shoot length of wheat stored at different time and cultivars in both Sakha and Sids warehouse are shown in Fig. (1-3). Storage at Sids warehouse had generally better preserving effect on germination percentage, root length and shoot length than storage at Sakha warehouse for all storage time and cultivars. In spite of, after 18 months, Misr 1 gave the highest germination, root length and shoot length. Meanwhile, after 18 months, Sakha 93 gave the lowest germination percentage, root length and shoot length compared with other cultivars at the same storage time and both Sakha and Sids warehouse. Also, the second order interaction between storage time, storage form and cultivar shown Fig. (4-6). In general, after 18 months, Sakha 93 gave the lowest viability (by increase moisture content, EC value and acidity percentage) at Sakha and Sids warehouse compared with other cultivars. These differences between cultivars might be due to the genetic factors and seed chemical composition influence the expression on seed deterioration and vigor decline Hummel et al (1954) and Robers (1972).

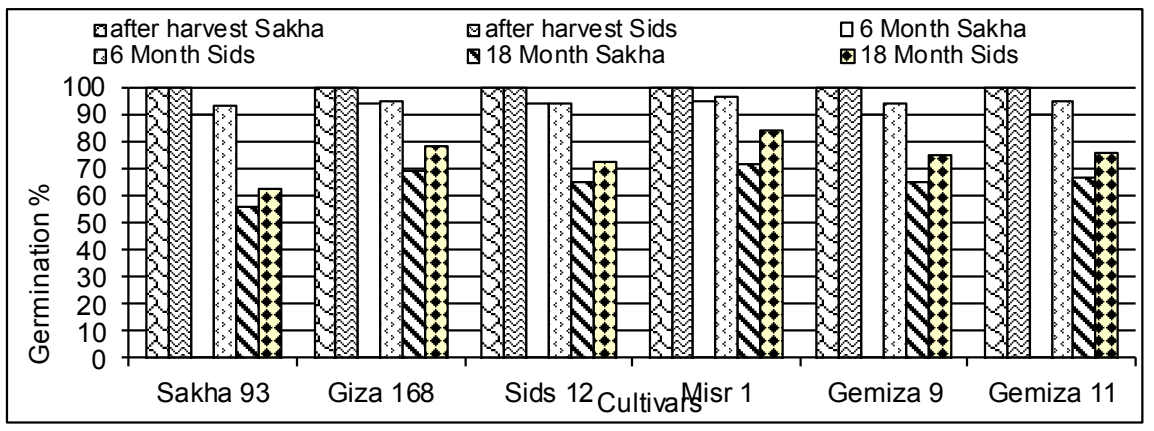

Fig 1. Effect of interaction between storage time, storage location and cultivar on germination

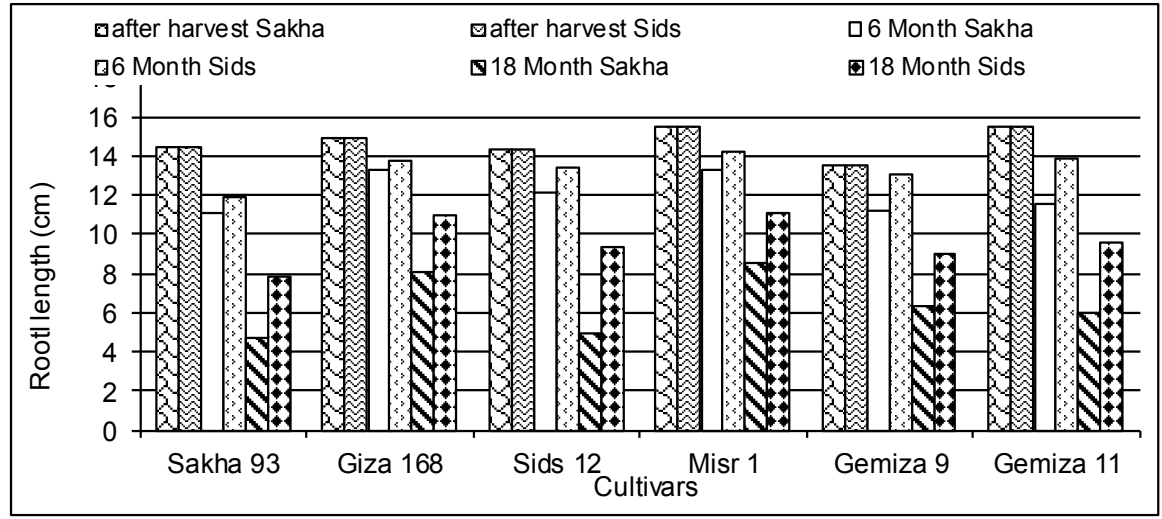

Fig 2. Effect of interaction between storage time, storage location and cultivar on root length.

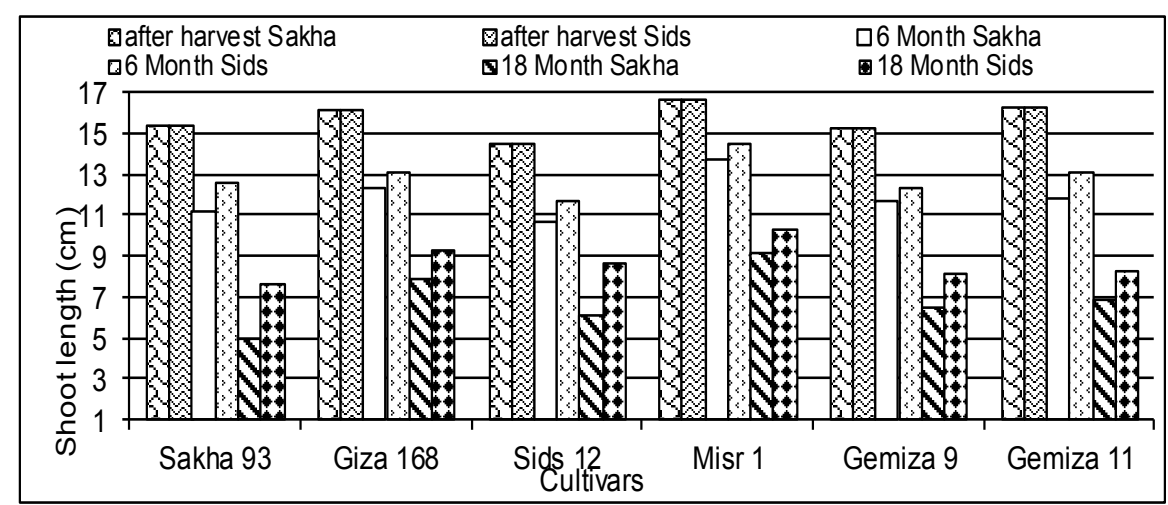

Fig 3. Effect of interaction between storage time, storage location and cultivar on shoot length 


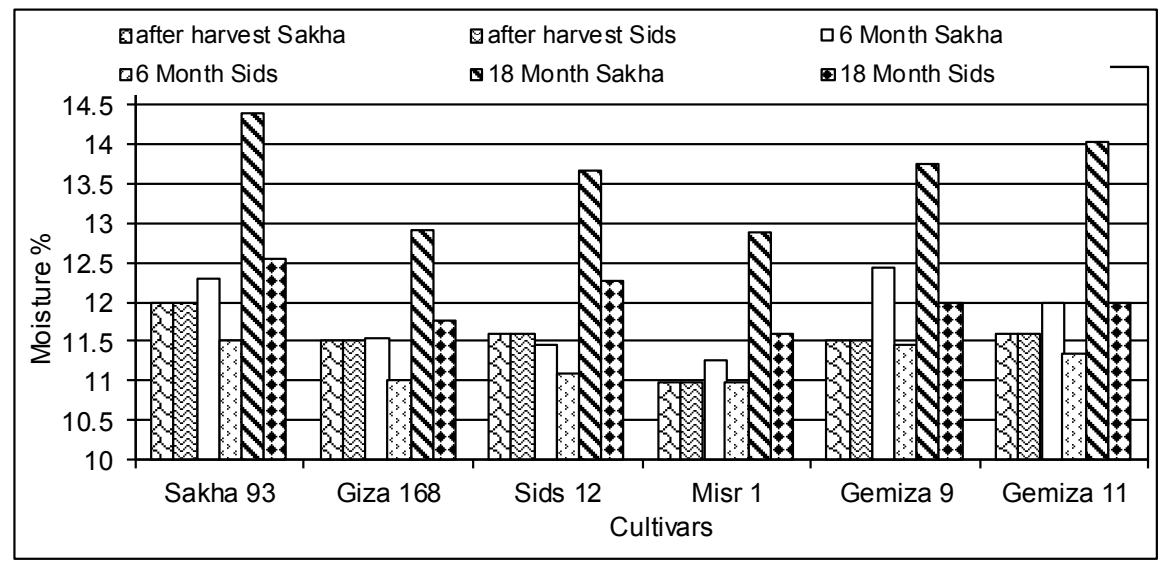

Fig 4. Effect of interaction between storage time, storage location and cultivar on moisture\%

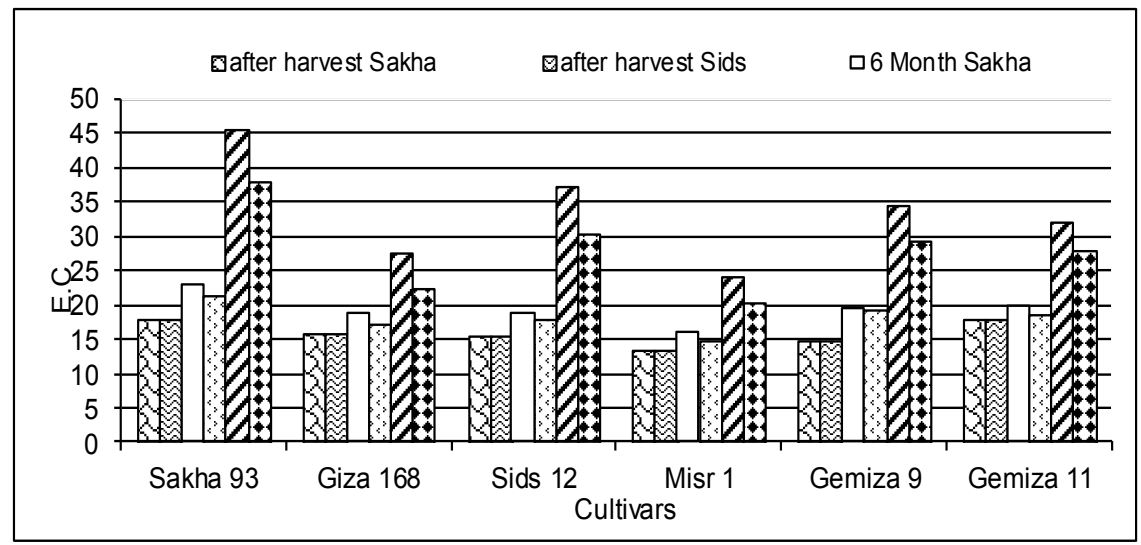

Fig 5. Effect of interaction between storage time, storage location and cultivar on E.C.

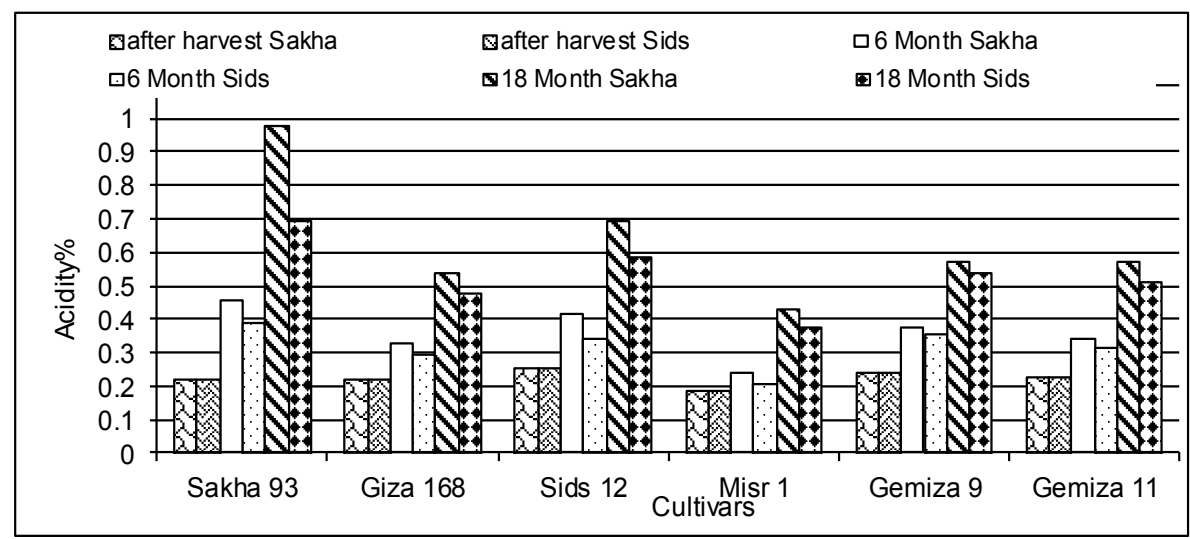

Fig 6. Effect of interaction between storage time, storage location and cultivar on acidity\% 


\section{Correlation coefficient}

The simple correlation coefficient (r) values presented in Table 9 indicate a positive correlation between germination percentage and each of root length; shoot length; seedling dry weight; 1000-seed weight; R.D and protein percentage. In addition, negative correlation between germination percentage and each of moisture content; E.C and acidity percentage. The data represented in Table 9 revealed that root length was highly significantly and positive with each of shoot length ; seedling dry weight; 1000-seed weight ; R.D and protein percentage , while it showed a significant negative association with each of moisture content; E.C value and acidity percentage. Furthermore, shoot length showed highly significant and strong positive correlation with both seedling dry weights; 1000seed weight; R.D and protein percentage, while it was significantly and negatively correlated with both moisture content, E.C value and acidity percentage. Meanwhile, seedling dry weight showed highly significant and positivly correlated with both 1000-seed weight; R.D and protein percentage, while it showed a significant negative association with both moisture content, E.C value and acidity percentage. Positive correlation was observed between moisture content and each of E.C value and acidity percentage, while it showed a significant negative association with protein percentage. Furthermore, E.C value percentage showed significant and strong positive correlation with acidity percentage, while it was significantly and negatively correlated with 1000 -seed weight and protein percentage. A-Negative correlation was observed between acidity percentage and both 1000 -seed weight, R.D and protein percentage. Meanwhile, 1000-seed weight showed highly significant and positive correlated with R.D and protein percentage. In addition, positive correlation between R.D and protein percentage. These results are consistent with those obtained by El- Sayed et al. (2004) and El-sayed et al. (2017) reported that the correlations between germination and each of root length and shoot length were positive and significant, while the correlations between crude protein, acidity value, moisture content, root length and shoot length were negative and significant.

\section{Conclusion}

We concluded that, spike form is better than grain form which maintains seed wheat quality and retains the viability of wheat seed among the three storage times. At the same time, Sids location has better condition than that of Sakha location. Among the six used wheat cultivars Misr1 cultivar was the most resistant one under different storage conditions.

TABLE 9. Correlation coefficients between means of studied characters for wheat cultivars under storage time, storage location and storage form

\begin{tabular}{|c|c|c|c|c|c|c|c|c|c|c|}
\hline & Characters & $\mathbf{X} 2$ & $\mathbf{X} 3$ & $\mathrm{X} 4$ & X5 & X6 & $\mathbf{X} 7$ & X8 & X9 & $\mathrm{X} 10$ \\
\hline $\mathrm{X} 1$ & Germination (\%) & $0.965 * *$ & $0.948 * *$ & & & $-0.942 * *$ & $-0.925 * *$ & $0.610 * *$ & $0.558 * *$ & $0.779 * *$ \\
\hline $\mathrm{X} 2$ & Root length (cm) & & $0.957 * *$ & & & $-0.936 * *$ & $-0.929 * *$ & $0.583 * *$ & $0.510 * *$ & $0.678 * *$ \\
\hline $\mathrm{X} 3$ & Shoot length $(\mathrm{cm})$ & & & & & $-0.904 * *$ & $-0.928 * *$ & $0.582 * *$ & $0.551 * *$ & $0.679 * *$ \\
\hline $\mathrm{X} 4$ & $\begin{array}{l}\text { Seedling dry } \\
\text { weight }\end{array}$ & & & & $-0.818 * *$ & $-0.891 * *$ & $-0.899 * *$ & $-0.899 * *$ & $0.541 * *$ & $0.618 * *$ \\
\hline $\mathrm{X} 5$ & Moisture (\%) & & & & & $0.845 * *$ & $0.787 * *$ & $0.605^{* *}$ & $-0.407 * *$ & $-0.552 * *$ \\
\hline $\mathrm{X} 6$ & $\mathrm{EC}$ & & & & & & $0.958 * *$ & $0.923 * *$ & $-0.827 * *$ & $-0.627 * *$ \\
\hline $\mathrm{X} 7$ & Acidity (\%) & & & & & & & $0.943 * *$ & $-0.852 * *$ & $-0.587 * *$ \\
\hline $\mathrm{X} 8$ & 1000- weight & & & & & & & $0.930 * *$ & $-0.736 * *$ & $0.520 * *$ \\
\hline X9 & Relative density & & & & & & & & & $0.595 * *$ \\
\hline $\mathrm{X} 10$ & Protein $(\%)$ & & & & & & & & & 1.00 \\
\hline
\end{tabular}

** Significant at 0.01 levels of probability. Means in same row following by the same latter (s) are not significantly different. 


\section{References}

A.O. A. C. (1990) Official Methods of Analysis of the Association of Official Analytical Chemists, $15^{\text {th }}$ edition, published by Association of Official Analytical Chemists Arlington, Virginia, U.S.A.

Abba, J.E. and Lovato. A. (1999) Effect of seed storage temperature and relative humidity on maize (Zea mays L.) seed viability and vigor. Seed Sci. Tech. 27 (1), 101-114.

Badawi, M. A., Seadh, S. E., Abido, W. A. E and Hasan, R. M. (2017) Effect of storage treatments on wheat storage. Int. J. Adv. Res. Biol. Sci. 4 (1), 78-91.

Copeland, L.O. and Mc Donald., M. B. (1995) Seed longevity and deterioration. Int. seed Sci. Techno., Chapman and Hill, PP. 181-220

Duncan, D.B. (1955) Multiple range and multiple F.Test. Biometrics II: 1-42.

El-Borai, M. A., El-Aidy, N. A. and El-Emery, M. (1993) Effect of different storage periods on seed quality of three soybean cultivars. J. Agric. Sci. Mansoura, 18 (8) 2206-2211.

EL-Sayed, S. A. (1997) Effect of storage conditions on seed quality of wheat and Faba bean. Ph. D. Thesis., Faculty of Agric., Kafr El-Sheikh, Tanta Univ. Egypt.

El-Sayed, S. A. and Tolba, S.A.E. (2005) Effects of storage condition and package kinds on germination, chemical composition by ear and kernel root diseases and oil quality in some maize grain genotypes. Alex.J.Agric.Res. 50 (2), 23-33.

El-Sayed, S. A. and Abd El- Aziz, M. N. (2005) Relationship of viability parameters and quality of viability parameters and quality of soybean under different storage condition. Tanta Univ. J. Agric. Res. 31 (4a), 675-691.

El-Sayed, S. A., Kineber, M. E. A. and El-Kady, E.A. (2004) Effect of storage environment and package material on storability, yield and its quality of flax seeds. J. Agric. Res. 30 (3), 616-638.

El-Sayed, S. A., Mohamed, E. N. M. and Mohamoud, B. A. (2017) The relationship between viability parameters and quality of cotton seed under different storage conditions. Egypt. J. Plant Breed. 21 (7), 1375-1390.

Harrington J. F. (1973) Packaging seeds for storage and shipment. Seed Sci. and Technology, 1, 701-709.

Harrington, J. F. (1972) "Seed storage and longevity" Int. Seed Biology, $3^{\text {rd, }}$ ed. New York: Academic,
Press T.T. Kozlowski. PP. 145-240.

Hummel, B. C. W., Christensen, L. S. C. M and Geddes, W. F. (1954) Grain storage studies XIII: Comparative changes in respiration, viability and chemical composition of mold-free and moldcontaminated wheat upon storage. Cereal Chem. 31, 143-150.

I.S.T.A. (1999). International rules for seed testing association. Seed Sci. and Technology 27, 155-165.

Kandil, A. A., Sharief, A. E. and Sheteiwy, M. S. (2013) Effect of seed storage periods, conditions and materials on seed quality of some soybean cultivars. Int. J. Agric. Sci., 5 (1), 339-346.

Karaoglu, M.M., Aydeniz, M., Kotancilar, H. G. and Gercelaslan, K. E. (2010) Acomparison of the functional characteristics of wheat stored as grain with wheat stored in spike form. Int. J. of Food sci. and Tech. 45, 38-47.

Kibar, H. (2015) Determining the functional characteristics of wheat and corn grains depending on storage time and temperature. J. Food Processing and Preservation.

Konopatskaia, I., Vavilova, V., Blinov, A. snd Goncharov, N. P. (2016) Spike morphology genes in wheat species (Triticum L.). Proceedings of The Latvin Academy of Sciences. 70(6): 345-355.

Kramer, A. and Twigg, B.A. (1962) Fundamentals of Quality Control for the Food Industry. AVI publishing Co. West port, CT, pp.512.

Krishnasamy, V. and Seshu, D.V. (1990) Germination after accelerated aging and associated characters in rice varieties. Seed Sci. Technol. 18, 147-156.

Magness, J.R., and Markle, C.C. (1971) Food and feed crops of the United States. Interregional Res. Project IR-4, IR Bul. 1 (Bul.828 New Jersey Agr, Expt. Sta.

Mersal, I. F., El- Emam, A. A. M. and Selim, A. H. (2006) Effect of storage periods, seed moisture content and insecticides treatments on wheat (Triticum aestivum L.) Seed quality. Ann. of Agric. Sci., Moshtohor, 44 (1), 111-124.

Miller, C.L. (2003) Variation in single kernel hardness within the wheat spike. B.S. thesis, Kansas State Univ.

Mrda, J., Crnobarae, J., Dusanie, N., Radie, V., Miladinovie, D., Joeie, S. and Miklie, V. (2010) Effect of storage period and chemical treatment 
on sunflower seed germination. HELIA, 33 (53), 199-206.

Nagel, M. and Borner, A. (2010) The longevity of crop seeds stored under ambient conditions. Seed Sci. Res. 20, 1-12.

Naguib, N.A., Mohamed, E. A. I., and El- Aidy, N. A. (2011). Effect of storage period and packaging material on wheat (Triticum aestivum L.) seed viability and quality. Egypt. J. Agric. Res., 89 (4), 1481-1497.

Nasreen, S. (1999). Effects of storage period and temperature on seed viability of wheat. Pakistan. J. Biol. Sci. 2, 1492-1493.

Odiemah, M. (1987) Germinability and vigor of wheat seed compartment at different periods of storage. Acta. Agronomica- Hungarica. 36 (3-4), 303-308.

Omar, A. M., Sorour, F. A., El- Sayed, S.A. and Shalaby, N. E. (2012) Effect of storage periods, cultivars, environments and package materials on germination, viability and seedling vigor of wheat grains. J. plant Production, Mansoura Univ. 3 (6), 1075-1087.
Roberts, E. H. (1972) Viability of Seeds. Chapman and Hall Co. Ltd., London.

Sendedcor, G.W. and Cochran, W.G. (1982) Statistical Methods Applied to Experiments in Agriculture and Biology. 7th ed. Seventh reprinting. The IOWA State Univ. Press. Ames, IOWA, U.S.A.

Shahein, A. M. E. A. and Mohamed, A. M. (2016) Storability of some oil seed crops under two types of packages. J. Plant Production, Mansoura Univ. 7 (12), 1411-1417.

Singh J. S. S., Shikha, A. S., and Bose, B. (2011) Studies on seed mycoflora of wheat (Triticum aestivum L.) treated with potassium nitrate and its effect on germination during storage. Res. J. of Seed Sci. 4 (3), 148-156.

Srivastava, A. K. and Rao, P. H. (1994) Changes in the functional characteristics of wheat during high temperature storage. J. of Food Sci. and Tech., 31, 36-39.

(Received: 1 / 6/2018; accepted:18 / $6 / 2018$ ) 


\section{دراسد تاثير بعضي الظروف التخزينيه على القدره التخزينيه لستة أصناف من قمح الخبز من مواقع مختلفة}

سعاد عبد الهادى السيد ، امانى محمود محمد و هيام إبراهيم عطيه الصاوي

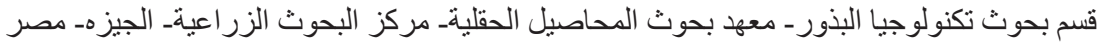

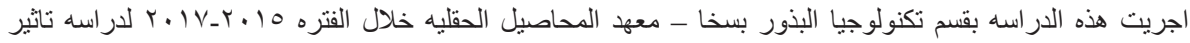

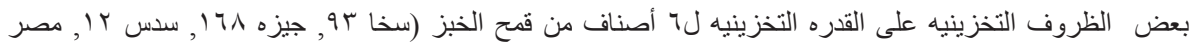

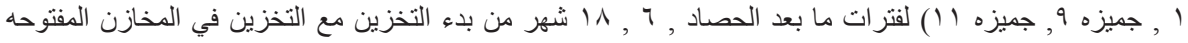

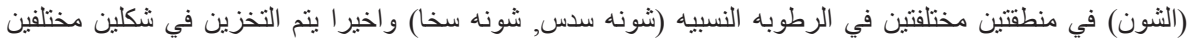

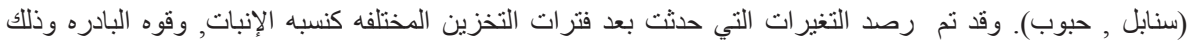

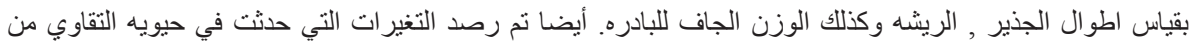

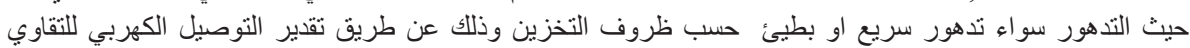

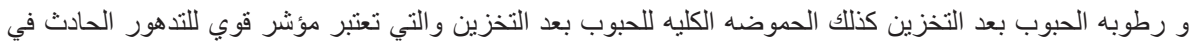

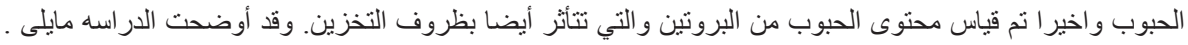
- لوحظ تغير ات معنويه في جميع الصفات تحت الدر اسه للأصناف المستخدمه في هذه الدر اسه. ـ كذللك هناك تأثير معنوي لتنأثير فترات التخزين لجميع الصفات تحت الدراسه

ـ هناك تأثير معنوي و اضح لظروف التخزين في منطقتين مختلفتين من حيث الرطوبه النسبيه (شونه سدس, كذلك شونه سخا)

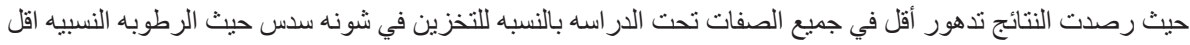

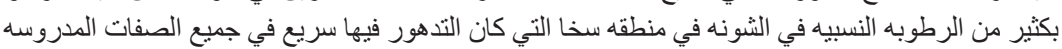
- رصدت أيضا النتائج المتحصل عليها تأثير معنوي لشكل التقاوي أثناء التخزين حيث اعطي التخزين في شكل سنابل نسبه

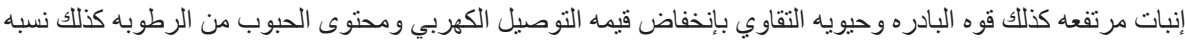

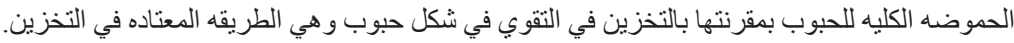

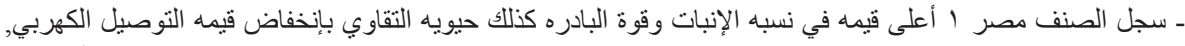

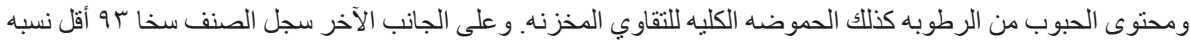

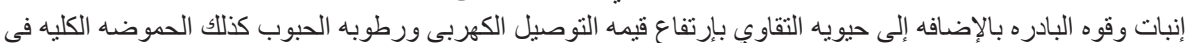
الحبوب بالدقارنه بالأصنف تحت الأضف الدراسه.

- ويمكن الإستفاده من هذه النتائج في كيفيه الحفاظ على حيويه تقاوي القمح لفتره موسمين زر اعيين بالتخزين في الأماكن

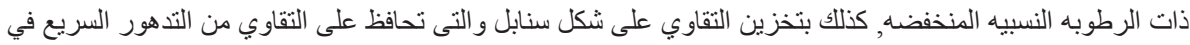
الإنبات وقوه البادره كذللك حيويه التقاوي. 